\title{
ФІТОЦЕНОТИЧНІ ПОЗИЦЇ̈ БАГАТОРІЧНИХ ЗЛАКІВ У СТЕПОВИХ ТА ШТУЧНИХ ЛІСОВИХ БІОТОПАХ НА ПРАВОБЕРЕЖЖІ ПРИСАМАР'Я (ДНІПРОПЕТРОВСЬКА ОБЛАСТЬ)
}

Показано участь багаторічних злаків, у тому числі за показником фітоценотичної активності, у травостої пробних площ, розташованих на правому березі ріки Самари від її берега до вододільних (плакорних) місцезростань. Всі згадані у статті види цієї групи рослин є потенційно цінними для практичного використання в умовах екологічної відповідності.

Ключові слова: багаторічні злаки, трав'яний покрив, фітоценотична активність, ерозія грунту, фітоіндикатори.

Л. П. Мыцык, Е. И. Лисовец, В. Н. Яковенко

Днепровский национальный университет имени Олеся Гончара

\section{ФИТОЦЕНОТИЧЕСКИЕ ПОЗИЦИИ МНОГОЛЕТНИХ ЗЛАКОВ В СТЕПНЫХ И ИСКУССТВЕННЫХ ЛЕСНЫХ БИОТОПАХ НА ПРАВОБЕРЕЖЬЕ ПРИСАМАРЬЯ (ДНЕПРОПЕТРОВСКАЯ ОБЛАСТЬ)}

Показано участие многолетних злаков, в том числе по показателю фитоценотической активности, в травостое пробных площадей, расположенных на правом берегу реки Самары от ее берега к водораздельным (плакорным) местообитаниям. Все упомянутые в статье виды этой группы растений являются потенциально ценными для практического использования в условиях экологического соответствия.

Ключевые слова: многолетние злаки, травяной покров, фитоценотическая активность, эрозия почвы, фитоиндикаторы.

\section{P. Mytsyk, O. I. Lisovets, V. M. Yakovenko \\ Oles Honchar Dniprovsky National University}

\section{PHYTOCOENOTIC POSITIONS OF PERENNIAL CEREALS IN STEPPE AND ARTIFICIAL FOREST HABITATS IN THE PRISMARIA'S RIGHT BOAT (DNEPROPETROVSK AREA)}

Perennial cereals - one of the most widespread groups of plants in the flora of Steppe Pridniprov'ya. They being here in all types of natural vegetation. In a practical relation a most value they have as components of pastures, lawns, ravine covers and other. For each of these setting it have to pick up species with different properties, but with general requirements. They must be high-efficiency from the practical point of view, proof in concrete habitat (in the conditions of ecological accordance) and able here to form a dense cover.

Attention to the perennial cereals is conditioned because types of this group of plants that is able to form a dense turf are the most powerful competitor of the forest in steppe terms.

However information from potential possibilities of corresponding types of plants is limited. It one of reasons of that placing of perennial cereals in the conditions of ecological accordance, often remains a wish only. For this reason we put on an aim to investigate dependence between the ecological mode of concrete natural habitat and presence and quantity here of certain species of perennial cereals.

As research objects are used 5 stationary geobotanical trial areas by sizes a $10 \times 10$ m, situated near Biosphere Station of the Oles Honchar Dniprovsky National University (village Andriyivka of the Novomoskovsk district of the Dnepropetrovsk area). Used the

(C) Л. П. Мицик, О. І. Лісовець, В. М. Яковенко, 2017 
classic methods of geobotanical researches. In June, 2012 within the limits of the areas marked higher took into account all species of plants and their project coverage. The role of a separate species in the structure of the vegetation was determined by its phytocoenic activity, the magnitude which we found by extracting the square root from the result of multiplication (product) of the digital indicators of projective coverage and occurrence. Researched soils are definite by according the international classification of WRB.

Classification of soil of the first trial area by WRB - Calcic Chernozem. Downward on the slope of right bank of River Samara influence of erosive procession on the ground cover increases, as a result black earth soils are characterized by the different degree of washed off of the ground horizons. As a result there is reduction to power of the ground profile in habitat on trial areas № 2 and № 3 and with wedging out maternal loamy breeds in positions of trial area № 4 . Valley habitat of trial area № 5 is substantially differ from the terms of watershed and slope by the complex of ecological factors of process of formation of soil, properties and modes of soils.

As appeared, on the whole on all areas 13 species of perennial cereals were present, that presented only $16,7 \%$ of floristic composition of cenosis, but their project coverage are a high index $-75,1 \%$. In terms of the average phytocenotic activity in all the study areas, all species of cereals can be located in a diminutive series, headed by Festuca valesiaca Gaud., Botriochloa ischaemum (L.) Keng and Stipa lessingiana Trin. Further, with less participation, Koeleria cristata (L.) Pers., Poa angustifolia L., Stipa capillata L., Poa compressa L., Bromopsis riparia (Rehm.) Holub, Elytrigia repens (L.) Nevski, Cleistogenes bulgarica (Bornm.) Keng, Melica transsilvanica Schur, Poa pratensis L., Calamagrostis epigeios (L.) Roth. were present.

However, depending on geomorphological position of trial areas, and thus, and from their general ecological properties, the role of these plants had considerable differences.

A structure of phytocenosis of trial areas, including correlation of perennial cereals and other plants, is typical for local conditions. Information, that they are characterized, in certain mathematical interpretation can serve as reliable basis for monitoring and other researches. Hydrological mode of watershed habitat appeared intermediate between of the real and meadow steppe, that conditioned by the presence of the close located forest belt, river of Samara and large forest array.

The idea of the need to preserve steppe vegetation on loamy slopes without replacing it with forest stands has been confirmed. However, we recommend the conservation of steppe areas with natural turf on all types of soils in any geomorphological conditions. All perennial cereals marked higher are potentially valuable for the practical use in the conditions of ecological accordance. The well possibility of the use of Poa angustifolia as a phytoindicator of viability of the forest planting was proved.

Keywords: perennial cereals, grass cover, phytocenotic activity, soil erosion, phytoindicators.

Багаторічні злаки - одна з найрозповсюдженіших груп рослин у флорі Степового Придніпров'я. Вони присутні тут у всіх типах природної рослинності. У практичному відношенні найбільше значення вони мають як компоненти пасовищ, сіножатей, газонів, протиерозійних покривів і т. ін. Для кожного $з$ цих призначень підбирають види з неоднаковими властивостями, але із загальними вимогами. Вони повинні бути високоефективними з практичної точки зору, стійкими у конкретному місцезростанні (в умовах екологічної відповідності) та здатні при цьому утворювати цупкий дерен.

Увага до багаторічних злаків обумовлена й тим, що види цієї групи рослин, які здатні утворювати щільний дерен, $є$ найпотужнішим конкурентом лісу в степових умовах. У зв'язку з цим нагадаємо влучний вислів Г. М. Висоцького про те, що в умовах степу «густой (особенно злаковый) дерн есть главный враг леса» [1]. Додамо, що вся історія степового лісорозведення та лісознавства - це сукупність знань про послідовні етапи створення насаджень у таких сполученнях різних видів деревних та чагарникових рослин, які можуть формувати режим неприступності під їх крони для трав'яних, передусім степових, видів, здатних утворювати дерен. 
Проте відомості з потенційних можливостей відповідних видів рослин у зазначеному вище ракурсі обмежені. Це одна з причин того, що розміщення трав в умовах екологічної відповідності часто лишається тільки побажанням. Саме тому ми поставили на меті дослідити залежність між екологічним режимом конкретних природних місцезростань і наявністю та чисельністю в їх межах певних багаторічних злаків. Такі відомості розширять уявлення про біолого-екологічні властивості цих рослин та можуть стати основою для практичних висновків.

Методи та об'єкти дослідження. Як об'єкти дослідження використані п'ять стаціонарних геоботанічних пробних площ розмірами $10 \times 10$ м, закладені нами близько біосферного стаціонару Дніпровського національного університету імені Олеся Гончара (село Андріївка Новомосковського району Дніпропетровської області). Використовували класичні методи геоботанічних досліджень. В червні 2012 року в межах зазначених вище площ ураховували всі види рослин та їх проективне покриття, що дозволило, крім іншого, за методом Л. Г. Раменського [10] визначити екологічний режим цих ділянок. Орієнтиром для останнього аналізу слугували також типологічні побудови О. Л. Бельгарда [3] з гідрологічною конкретизацією Л. П. Травлєєва [14] та наша класифікація об'єктів задернення [9].

Зазначені вище площі, будучи розташованими ланцюжком перпендикулярно до правого берега ріки Самари, охоплюють різноманітні геоморфологічні та фітоценотичні позиції від вододільних (плакорних, зональних) до долинних умов.

Роль окремого виду в структурі рослинного покриву визначали за його фітоценотичною активністю (ФА), величиною, яку ми знаходили добуванням квадратного кореня з результату перемноження (добутку) цифрових показників проективного покриття та трапляння. Останній визначали урахуванням присутності особин конкретного виду на площах, обмежених рамками розмірами $0,5 \times 0,5 \mathrm{M}$. На кожній площі величиною $10 \times 10$ м закладали по 100 таких одиниць (разом $\left.25 \mathrm{M}^{2}\right)$.

Досліджені грунти визначені за міжнародною класифікацією WRB [16] та 3 використанням номенклатури грунтів Комплексної експедиції Дніпровського національного університету з вивчення природних та штучних лісів степової зони України (КЕДУ). Карбонатність грунтів визначалася за деталізованою шкалою В. Г. Стадніченка [12].

Умови зволоження визначалися за Л. П. Травлєєвим [15], макроморфологічний опис грунтів - за Б. Г. Розановим [11].

Результати та їх обговорення. Пробні площі розташовані на вододілі між Самарою та іiі притокою річкою Сороковушкою. Перша пробна ділянка закладена близько стаціонарної пробної площі № 201-В генерального геоморфологічного профілю Комплексної експедиції Дніпровського національного університету імені Олеся Гончара на схилі в $2^{\circ}$ північно-східної експозиції. Грунтоутворюючі породи - леси середньосуглинкового гранулометричного складу. Тип лісорослинних умов - суглинок сухий (СГ0-1). Зволоження атмосферне, грунтові води на глибині понад 40 м. Різні горизонти грунту мають такі властивості.

Н0 (2-0 см) - одношарова, фрагментарна повсть.

H1d (0-4 см) - перший гумусово-акумулятивний дерновий горизонт. Свіжий, темно-сірого забарвлення, середньосуглинковий, структура пилувато-дрібнозернисто-дрібногрудкувата. Пухкого складення. Рясно насичений коренями трав'яних рослин. Перехід за структурою і щільністю складення.

$\mathrm{H}_{2}$ (4-30 см) - другий гумусово-акумулятивний горизонт. Свіжий, темно-сірого кольору, середньосуглинковий, структура зернисто-грудкувата, щільніше за поверхневий горизонт, корененасичений. Перехід за забарвленням і структурою.

Hpk $(30-46$ см) - перший перехідний карбонатний горизонт. Свіжий. Основний колір - темно-палевий з жовто-палевими плямами. Середньосуглинкового гранулометричного складу. Структура зернисто-грудкувата, крупніша за попе- 
редній горизонт. Щільність складення подібна до горизонту $\mathrm{H}_{2}$. Значно менший вміст коренів. Закипання з глибини 32 см. Перехід за забарвленням, структурою та щільністю.

Phk (46-65 см) - другий перехідний карбонатний горизонт. Свіжий. Неоднорідно забарвлений, палевий, з жовто-палевими плямами. Середньосуглинкового гранулометричного складу. Структура грудкувато-призматична, щільнішого складення. Значно менший вміст коренів. Інтенсивне закипання карбонатів. Перехід за забарвленням, структурою, щільністю складення і вмістом карбонатів.

P1К (65-85 см) - материнська карбонатна лесова порода. Свіжа. Забарвлення неоднорідне: на жовто-палевому загальному фоні спостерігаються сірі плями і канали з гумусовим матеріалом та бруднобілі новоутворення карбонатів різної концентрації (від суцільно білої білозірки до «зникаючих» плям і вицвітів). Гранулометричний склад середньосуглинковий. Структура крупніша за попередні горизонти: дрібні агрегати - грудкуваті; середні - призматичні; крупні - брилисті. Порівняно $з$ попереднім горизонтом, у призматичних окремостей різкіше виражені ребра. Найщільніший горизонт профілю. Характеризується максимальним вмістом карбонатів (відзначається бурхливим закипанням). Перехід за забарвленням, вмістом карбонатів, структурою і щільністю.

$\mathrm{P}_{2} \mathrm{k}$ (85-150 см) - карбонатний лес. Свіжий, жовто-палевий з білувато-сірим. Зустрічаються поодинокі темно-сірі гумусові затікання по вертикальних ходах землериїв і коренів та окремі плями білозірки. Але в цілому забарвлення має більш однорідний вигляд у порівнянні з попереднім горизонтом. Гранулометричний склад важкосуглинковий. Морфологія структурних окремостей: дрібні - грудкуваті; середні - призматичні; крупні - брилисті. Порівняо з попереднім горизонтом менша щільність складення та інтенсивність закипання карбонатів (концентрації у вигляді псевдоміцелію).

Класифікація грунту за WRB - Calcic Chernozem. Повна назва грунту за номенклатурою КЕДУ - чорнозем звичайний карбонатний середньопотужний середньосуглинковий на лесах.

Наведена морфологічна характеристика профілю чорноземів звичайних є типовою для плакорних грунтів і характеризує екологічні умови місцезростань у межах пробної площі № 1. Варто зазначити, що вниз по схилу правого берега p. Самари посилюється вплив ерозійних процесів на грунтовий покрив, внаслідок чого чорноземні грунти характеризуються різним ступенем змитості грунтових горизонтів. У результаті спостерігається зменшення потужності грунтового профілю в місцезростаннях пробних площ № 2 і № 3 та з виходом на поверхню материнських суглинкових порід у позиціях пробної площі № 4. Долинні місцезростання пробної площі № 5 суттєво відрізняються від умов плакору і схилу комплексом екологічних факторів грунтоутворення, властивостями і режимами грунтів.

Як виявилося, загалом на усіх площах були присутні 13 видів багаторічних злаків, що становило тільки 16,7 \% флористичного складу дослідженого травостою, але за проективним покриттям вони мають більше значення $-75,1 \%$. За середньою ФА, на усіх досліджених ділянках, вишикувався зменшувальний ряд, який очолили костриця валіська (Festuca valesiaca Gaud.), бородач звичайний (Botriochloa ischaemum (L.) Keng) та ковила Лессінга (Stipa lessingiana Trin. et Rupr.). 3 меншою участю були присутні келерія гребінчаста (Koeleria cristata (L.) Pers.), тонконіг вузьколистий (Poa angustifolia L.), ковила волосиста (Stipa capillata L.), тонконіг стиснутий (Poa compressa L.), стоколос прибережний (Bromopsis riparia (Rehm.) Holub), пирій повзучий (Elytrigia repens (L.) Nevski), зміївка болгарська (Cleistogenes bulgarica (Bornm.) Keng), перлівка трансільванська (Melica transsilvanica Schur), тонконіг лучний (Poa pratensis L.), куничник наземний (Calamagrostis epigeios (L.) Roth.). Проте, залежно від геоморфологічного положення 
пробних площ, а отже, і від їх загальних екологічних властивостей, роль цих рослин мала значні відмінності.

Сезонна динаміка рослинності зазначених вище пробних площ показана раніше [7], тому тут покажемо лише їх загальну фітоценотичну структуру.

На першій площі, розташованій на плакорі близько вододілу, на ділянці з деяким схилом $\left(2-3^{\circ}\right)$ на північ, зареєстровано 11 видів багаторічних злаків. Домінували тут костриця валіська $(\Phi А-9,66)$ та келерія гребічаста $(\Phi А-8,47)$. Меншою тут була участь тонконога вузьколистого, бородача звичайного та стоколосу прибережного, пирію повзучого, ще менша присутність зміївки болгарської, тонконога стиснутого, ковили волосистої, ковили Лессінга та перлівки трансільванської. За термінологією та індексацією Л. Г. Раменського, ця площа має проміжний характер між «середньостеповим» та «лучностеповим» гідрологічними режимами з балом 46,3. Для орієнтиру зазначимо, що за цією методикою, зволоження «середньостепове» обмежується показниками 40-46, «лучностепове» - 47-52. Загальна видова насиченість цієї площі становила 62 види рослин на 100 м². Порівняймо, у заповіднику «Хомутовський степ» (Донецька область) цей показник коливався від 25 (монодомінантна асоціація Elytrigetum trichophorum purum) до 60 (асоціація Stipa lessingiana + Festuca sulcata + Salvia nutans) [4]. У заповідному степу «Михайлівська цілина» (Сумська область, лісостепова зона) на 1991 рік в асоціації Poeta angustifoliae (зі співедифікатором Elytrigia repens) цей показник становив 35 видів на $100 \mathrm{~m}^{2}$, а в асоціації Bromopsidetum inermis purum - 28 [13]. Проте існує повідомлення й про

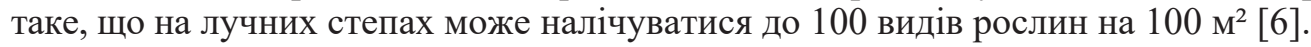

На другій площі, теж розташованій на плакорі, близько вододілу, але на незначному схилі $\left(5-7^{\circ}\right)$ південної експозиції, зволоження «середньостепове» (бал $45,7)$. Отже, дещо сухіше проти попередньої площі, хоч за своїм показником майже проміжне між «середньостеповим» та «лучностеповим». Тут зареєстровано 10 видів багаторічних злаків. Присутні ті самі види, що і на першій площі, крім перлівки трансільванської, але найчисленнішою була ковила волосиста $(\Phi А-7,05)$. Дещо менша участь у травостої бородача звичайного, костриці валіської, келерії гребінчастої, тонконога стиснутого, стоколоса прибережного та ін. Показник загальної видової насиченості - 52.

Третя площа розташована нижче другої по схилу $\left(10-12^{\circ}\right)$ південної експозиції. Зволоження тут типове «середньостепове» з балом 41,9. Це ділянка відмираючого насадження робінії звичайної (акації білої) (Robinia pseudoacacia L.) з розрідженістю в такій мірі, що між деревними особинами вільно розмістилася пробна площа розмірами $10 \times 10$ м. Присутні тут 8 багаторічних злаків, проте домінуюче положення - за ковилою Лессінга $(\Phi А-14,02)$. Проективне покриття лише цієї рослини становило 85 \%, інших багаторічних злаків (перлівки трансільванської, костриці валіської, бородача звичайного, тонконога стиснутого, стоколоса прибережного, зміївки болгарської, куничника наземного) - від 1 \% до 3 \%. Загальна видова насиченість - 33 .

Четверта пробна площа розташована нижче попередньої на найкрутішому (серед інших досліджених площ) схилі південної експозиції (20-25). Через це грунт надто змитий: на більшості цієї території - відкритий лесоподібний суглинок, місцями утворились яружки до 0,5-1,0 м глибиною. Це масив того самого відмираючого деревного насадження, що і на попередній площі. Тут присутні лише 7 багаторічних злаків. Проте безроздільне панування за бородачем звичайним (ФА - 9,50). Проективне покриття всього травостою - 50 \%, але тільки бородача -38 \%. Цей показник у інших багаторічних злаків (зміївка болгарська, стоколос прибережний, тонконіг стиснутий, костриця валіська, ковила Лессінга, келерія гребінчаста) становив 1-2 \%. Загальна видова насиченість - 42 .

П'ята площа закладена на горизонтальному місцеположенні, на високому правому березі ріки Самари, на лісовій галявині. Зволоження тут «лучностепове» 
3 балом 51,5, але майже на межі з «сухолучним» (це зволоження, за методикою Л. Г. Раменського, має бал 53-63). Тут зареєстровано тільки 4 багаторічні злаки. Співдомінантами цього фітоценозу були пирій повзучий $(\Phi А-8,80)$ та тонконіг вузьколистий (ФА - 7,98), з проективним покриттям відповідно - 38 \% та 34 \%. Загальне проективне покриття травостою - близько 85 \%. Решта ділянки - відкритий грунт, що обумовлено викошуванням та інтенсивнішим випасанням у порівнянні з іншими площами. Проективне покриття інших багаторічних злаків, тонконога стиснутого та тонконога лучного, становило відповідно 5 \% та $1 \%$. Загальна видова насиченість - 35 (включно зі сходами деревних і чагарникових рослин та моху).

Загальна ФА багаторічних злаків не мала суттєвої залежності від багатства грунту, але простежувалася тенденція іiї зменшення на бідніших місцезростаннях. Найменшим цей показник був на площі № 4 зі змитим грунтом. Багатство останнього, за методикою Л. Г. Раменського, становило 12,4 бали (для порівняння, на інших пробних площах - 12,5-14,0). Спостерігалася пряма залежність 3 гідротопом: багаторічні злаки мали найвищий показник ФА на найвологішій пробній площі (№ 5) із зволоженням, за згаданою вище шкалою, 51,5 бала (на інших площах $-41,9-46,3)$.

Викладені відомості, крім іншого, мають суттєву вагу як такі, що об'єктивно показують стійкість та деякі інші позитивні властивості наведених вище рослин у різних місцевих умовах. Значення цих даних стане зрозумілим, коли зважити на те, що, крім тонконога лучного, ні один із згаданих вище видів рослин досі не використовується у Степовій Україні для довготривалих трав'яних покривів (пасовища, сіножаті, газони, протиерозійні влаштування і т. ін.) та для іншого призначення, незважаючи на їх відповідні позитивні властивості.

Наприклад, тонконіг вузьколистий можна використовувати як надійний індикатор життєвості лісових насаджень у степових умовах. Прикладом є обстеження лісосмуги, розташованої близько пробної площі № 1, в якій домінувала акація біла (Robinia pseudoacacia L.) з підліском із свидини кров'яної (Swida sanguinea (L.) Opiz), розосередженої нерівномірно. Тут тонконіг вузьколистий у середній частині деревної смуги траплявся лише окремими особинами та розрідженими групками, дернового покриву не утворював i, отже, не був конкурентоспроможним стосовно до деревних та чагарникових рослин (досліджувалися 30 пробних площ розміром $1 \times 1$ м, закладених уздовж середньої частини лісосмуги). Трапляння тонконога становило тут 6,7 \%, при середньому проективному покритті 0,2%. У контролі, де травостій розташований стрічкою поруч з південною стороною лісосмуги, з боку сільськогосподарського угіддя, ці показники були відповідно - 100 \% та 26,4 \% (тут такі саме площі у тій же кількості закладені ланцюжком на відстані 3 м від крайнього стовбура деревного насадження). Отже, за цими відомостями, досліджена лісосмуга досить стійка, 3 високою життєвістю, принаймні на час виконання зазначеної роботи.

Наведені у цій статті дані підтверджують викладений раніше висновок «про доцільність збереження степових ділянок на сухих суглинистих схилах, де ліс росте погано, та, навпаки, створення соснових культур на легких грунтах еродованих схилів» [2]. Додамо, проте, що степові ділянки з природним дерновим покривом необхідно зберігати на схилах з грунтами будь-якого гранулометричного складу через такі причини: 1. «Флора цих цілинок містить цінні рослини, в першу чергу лікарські (горицвіт весняний, чебреці, астрагал пухнастоквітковий та ін.)» [8]; 2. Степові ділянки із зазначеними вище властивостями надійно протистоять ерозії на схилах з будь-яким грунтовим покривом; 3. Цілинні степові «острови», що збереглися на різноманітній геоморфологічній основі, $є$ значною цінністю як об'єкти незайманої природної одиниці та наукових досліджень (в Україні збереглося степових цілинних ділянок за площею менше 1 \% від первісного, доагрикультурного стану). Ці осередки степу - «залишки колишнього природного багатства, національної спадщини..., i їх необхідно врятувати» [5]. 
Висновки. Структура травостою пробних площ, у тому числі співвідношення багаторічних злаків та інших рослин, є типовими для місцевих умов. Відомості, що їх характеризують, у певній математичній інтерпретації можуть служити надійною основою для моніторингових та інших досліджень.

Гідрологічний режим плакорних місцезростань виявився проміжним між таким справжнього та лучного степу, що обумовлено наявністю близько розташованої лісосмуги, ріки Самари та великого лісового масиву.

Підтверджено думку про необхідність збереження степової рослинності на суглинистих схилах, не заміщуючи їх лісовим насадженням [2]. Проте степові ділянки з природним дерном необхідно зберігати незалежно від різновиду грунтового покриву та геоморфологічного положення конкретної ділянки.

Всі багаторічні злаки, зазначені вище у статті, є потенційними для розмноження та практичного використання в умовах екологічної відповідності. Доведено можливість використання тонконога вузьколистого як фітоіндикатора життєздатності лісового насадження.

\section{Бібліографічні посилання}

1. Альбицкая M. $\boldsymbol{A}$. Основные закономерности формирования травяного покрова в искусственных лесах степной зоны УССР / Искусственные леса степной зоны Украины. Харьков: Гос. ун-т, 1960. С. 149-208.

2. Альбицька М. О., Мороз О. Б., Сидельник М. О. Фітомаса штучних насаджень еродованих схилів Присамар'я та їх вихідних місцезнаходжень / 6-й з 'їзд Украӥнського ботан. тов-ва. Київ: Наук. думка, 1977. С. 238.

3. Бельгард А. Л. Степное лесоведение. Москва: Лесная пром., 1971. 336 с.

4. Быстрицкая T. Л., Осычнюк Т. Л. Почвы и первичная биологическая продуктивность степей Приазовья (на примере заповедника «Хомутовская степь»). Москва: Наука, 1975. $111 \mathrm{c}$.

5. Вакаренко Л. П. До розробки Буджацько-Старобільської екомережі. Збереження степів Украӥни. Київ: Академперіодика, 2002. С. 59-65.

6. Голубев В. Н. Эколого-биологические особенности травянистых растений и растительных сообществ лесостепи. Москва: Наука, 1965. 287 с.

7. Лісовець О. I. Сезонна динаміка трав'янистих фітоценозів Присамар'я. Питання степового лісознавства та лісової рекультиваиї̈ земель. 2007. Вип. 11 (36). С. 33-41.

8. Мороз О. Б. К вопросу о фитомелиорации эродированных местообитаний Присамарья Вопросы степного лесоведения и охраны природы. 1977. С. 82-85.

9. Мыцык Л. П. Опыт классификации объектов задернения (травянистых местообитаний) по признаку глубины залегания грунтовых вод. Екологія та ноосферологія. 2003. T. 14, № 3-4. С. 22-28.

10. Экологическая оценка кормовых угодий по растительному покрову. Л. Г. Раменский, И. А. Цаценкин, О. Н. Чижиков, Н. А. Антипин. Москва: Гос. изд-во с.-Х. лит., 1956. 472 с.

11. Розанов Б. Г. Морфология почв. Москва: Академический Проект, 2004. 432 с.

12. Стадниченко В. Г. Почвы Велико-Анадольского леса Науч. зап. Днепропетровского гос. ун-та. Велико-Анадольский лес. Харьков: ХГУ, 1955. Т. 48. С. 53-62.

13. Ткаченко В. С., Генов А. П., Лисенко Г. М. Структура рослинності заповідного степу «Михайлівська цілина» (Україна) за даними великомасштабного картування 1991 p. Укр. ботан. журн. 1993. Т. 50, № 4. С. 5-15.

14. Травлеев Л. П. О локальних коэффициентах увлажнения эдафотопов в лесных биогеоценозах степной Украины. Bопросы степного лесоведения и охраны природы. Днепропетровск: ДГУ, 1976. Вып. 6. С. 3-43.

15. Травлеев Л. П. Гидрологические основы типологии искусственных лесов степной зоны. Биогеоценологические исследования степных лесов, их охрана и раџиональное использование. Днепропетровск: ДГУ, 1982. Вып. 13. С. 36-65.

16. IUSS Working Group WRB 2014. World Reference Base for Soil Resources 2014. World Soil Resources Reports 106, FAO, Rome.

Надійшла до редколегії 15.10.2017 p. 